\title{
Inter-comparison of lidar and ceilometer retrievals for aerosol and Planetary Boundary Layer profiling over Athens, Greece
}

\author{
G. Tsaknakis ${ }^{1}$, A. Papayannis ${ }^{1}$, P. Kokkalis ${ }^{1}$, V. Amiridis ${ }^{2}$, H. D. Kambezidis ${ }^{3}$, R. E. Mamouri ${ }^{1}$, G. Georgoussis ${ }^{4}$, and \\ G. Avdikos ${ }^{4}$ \\ ${ }^{1}$ Laser Remote Sensing Unit, Department of Physics, National Technical University of Athens, Heroon Polytechniou 9, \\ Zografou Campus, 15780 Athens, Greece \\ ${ }^{2}$ Institute for Space Applications and Remote Sensing, National Observatory of Athens, Greece \\ ${ }^{3}$ Atmospheric Research Team, Institute of Environmental Research and Sustainable Development, National Observatory of \\ Athens, Lofos Nymphon, 11810 Athens, Greece \\ ${ }^{4}$ Raymetrics S.A., Peania, Athens, Greece
}

Received: 23 November 2010 - Published in Atmos. Meas. Tech. Discuss.: 10 January 2011

Revised: 13 May 2011 - Accepted: 22 June 2011 - Published: 29 June 2011

\begin{abstract}
This study presents an inter-comparison of two active remote sensors (lidar and ceilometer) to determine the mixing layer height and structure of the Planetary Boundary Layer (PBL) and to retrieve tropospheric aerosol vertical profiles over Athens, Greece. This intercomparison was performed under various strongly different aerosol loads/types (urban air pollution, biomass burning and Saharan dust event), implementing two different lidar systems (one portable Raymetrics S.A. lidar system running at $355 \mathrm{~nm}$ and one multi-wavelength Raman lidar system running at $355 \mathrm{~nm}, 532 \mathrm{~nm}$ and $1064 \mathrm{~nm}$ ) and one CL31 Vaisala S.A. ceilometer (running at $910 \mathrm{~nm}$ ). Spectral conversions of the ceilometer's data were performed using the Ångström exponent estimated by ultraviolet multi-filter radiometer (UV-MFR) measurements. The inter-comparison was based on two parameters: the mixing layer height determined by the presence of the suspended aerosols and the attenuated backscatter coefficient. Additionally, radiosonde data were used to derive the PBL height. In general, a good agreement was found between the ceilometer and the lidar techniques in both inter-compared parameters in the height range from $500 \mathrm{~m}$ to $5000 \mathrm{~m}$, while the limitations of each instrument are also examined.
\end{abstract}

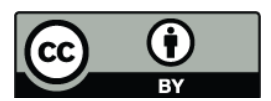

Correspondence to: A. Papayannis (apdlidar@central.ntua.gr)

\section{Introduction}

The dynamics of the Planetary Boundary Layer (PBL) are directly influenced by the Earth's surface, solar irradiance and anthropogenic activities. Air pollution concentrations in the PBL are generally orders of magnitude higher than those in the free troposphere (Stull, 1988). Additionally, heat and moisture from the surface must first be mixed through the PBL before being available to the circulation of the free troposphere. Consequently, studies of atmospheric dynamics in the troposphere very frequently employ PBL height data. Moreover, the influences of anthropogenic activities and earth's surface upon air quality can be monitored by studying the aerosol concentration and their relevant optical, microphysical and chemical properties (Seinfeld and Pandis, 2006).

Laser remote sensors, such as lidars and ceilometers, are proven to be powerful tools for tracking and monitoring the evolution of the PBL height (Papayannis and Balis, 1998; Amiridis et al., 2007), as well as the vertical profiles of aerosol properties over long time periods (Amiridis et al., 2005). The backscatter intensity of the returned signal depends mainly on the particulate concentrations in the air, but also on their reflective properties which are related to their moisture content (e.g. Angelou et al., 2011). Therefore, the lidar techniques are useful for three dimensional mapping of aerosols, remote sensing of ambient air pollutants, industrial emissions, and natural aerosol emissions due to volcanoes eruptions (Wang et al., 2008), biomass burning (Amiridis et al., 2009) and desert dust transport events (Papayannis et al.,

Published by Copernicus Publications on behalf of the European Geosciences Union. 
Table 1. Technical properties of the CL31 ceilometer and the Raymetrics and NTUA lidars. Typical uncertainties on the retrieved values of the attenuated backscatter coefficient, the mixing and cloud height are also given.

\begin{tabular}{|c|c|c|c|}
\hline & CL31 ceilometer & Raymetrics lidar & NTUA lidar \\
\hline Measurement range $(\mathrm{m})$ daytime/nighttime & $70-7500$ & $200-10000$ & $1000-15000$ \\
\hline Range resolution (m) & $5 / 10($ selectable $)$ & 7.5 & 15 \\
\hline Laser system & InGaAs MOCVD laser diode & Quantel Big Sky CFR 200 & Quantel Brilliant \\
\hline Wavelength (nm) & 905 & 355 & $355 / 532 / 1064$ \\
\hline Laser pulse energy (mJ) & $1.2 \times 10^{-3}$ & 40 & $75 / 150 / 400$ \\
\hline Laser pulse duration (ns) & 110 & 10 & 5 \\
\hline Mean pulse repetition rate $(\mathrm{Hz})$ & 8192 & 10 & 10 \\
\hline $\begin{array}{l}\text { Typical uncertainty on attenuated } \\
\text { backscatter coefficient } \\
\text { ( } 30 \text { min average time) }\end{array}$ & $\pm 20 \%$ & $\pm 20--30 \%$ & $\pm 20--30 \%$ \\
\hline $\begin{array}{l}\text { Typical uncertainty on mixing height } \\
\text { determination ( } 30 \text { min average time) (m) }\end{array}$ & \pm 200 & \pm 100 & \pm 100 \\
\hline $\begin{array}{l}\text { Typical uncertainty on cloud height } \\
\text { determination for } 30 \mathrm{~min} \text { average }(\mathrm{m})\end{array}$ & \pm 10 up to 200 & \pm 15 up to 200 & \pm 15 up to 200 \\
\hline
\end{tabular}

2005, 2008, 2009). On the other hand, ceilometers are devices used mostly for measuring the height of cloud bases by aerosol detection (e.g. Martucci et al., 2010).

Both lidars and ceilometers involve laser light backscattering measurements to determine the attenuated backscatter coefficient, from which the aerosol backscatter coefficient could be also retrieved (Klett, 1981) and thus, to obtain the cloud base (Martucci et al., 2010) or the PBL height (Eresmaa et al., 2006, 2009; McKendry et al., 2009; Heese et al., 2010). According to Markowicz et al. (2008), the fact that the laser light source used in ceilometers is less powerful and spectrally broader compared to that of a lidar system, the ability of ceilometers to detect aerosols is limited up to around $3 \mathrm{~km}$ height. Recently, Heese et al. (2010) compared aerosol backscatter coefficient profiles retrieved by a new generation CHM15K-X Jenoptik ceilometer and the IfT's lidar Polly in Leipzig (Germany) and suggested that the ceilometer is able to detect aerosol layers in the PBL and also in the free troposphere up to altitudes of the order of $4 \mathrm{~km}$ during day time, while during nighttime, this altitude may extend higher, depending on the aerosol load present.

In this study, the attenuated backscatter coefficient profiles obtained by a CL31 ceilometer owned by the National Observatory of Athens were evaluated against quality assured aerosol profiles obtained by the National Technical University of Athens (NTUA) and Raymetrics S.A. lidar systems, over a highly polluted urban site, such as the Athens Basin. The data were obtained under strongly different aerosol-type presences (urban pollution, biomass burning and Saharan dust event). Section 2 briefly presents the instrumentation involved in this study. Sections 3 and 4 show an intercomparison of the PBL height and the attenuated backscatter coefficient, respectively, as retrieved by ceilometer and lidar measurements. Finally, Sect. 5 presents our conclusions.

\section{Instrumentation}

\subsection{Ceilometer}

The ceilometer used in this study is a Vaisala CL31 model, described in detail in Münkel and Räsänen (2004), Münkel et al. (2007) and Emeis et al. (2008). In brief, CL31 is equipped with an InGaAs/MOCVD (Indium Gallium Arsenide/MetalOrganic Chemical Vapor Deposition) pulsed diode laser emitting at $905 \pm 10 \mathrm{~nm}$ and having an energy per pulse of $1.2 \mu \mathrm{J} \pm 20 \%$ (factory adjusted). The emission frequency is $8.19 \mathrm{kHz}$, while the pulse duration is $110 \mathrm{~ns}$. Briefly, CL31 uses a novel single (common) lens design, whose main innovation is in the way the common lens is used for transmitting and receiving light. The centre of the lens is used for collimating the outgoing laser beam, whereas the outer part of the lens is used for focusing the backscattered light onto the receiver. The division between transmitting and receiving areas is provided by an inclined mirror with a hole in the centre. This arrangement significantly reduces the optical cross-talk between transmitter and receiver. According to the Vaisala User's Guide (2009) the full overlap height of the instrument is achieved for altitudes higher than $10 \mathrm{~m}$, although in practice is on the order of $70 \mathrm{~m}$ (Martucci et al., 2010). The separation between the two areas is achieved by an oblique mirror. The backscattered data are acquired and stored by a $60 \mathrm{MHz}$ digital processor and stored in a hard disk unit. Thus, the attenuated backscatter coefficient is obtained from $70 \mathrm{~m}$ up to $7.5 \mathrm{~km}$ height (Münkel et al., 2007), with a selectable spatial resolution of 5 or $10 \mathrm{~m}$ and temporal resolution of $2 \mathrm{~s}$ to $120 \mathrm{~s}$ (Vaisala User's Guide, 2009). In our case we used $10 \mathrm{~m}$ raw range resolution and $2 \mathrm{~s}$ raw temporal resolution. 
(a)

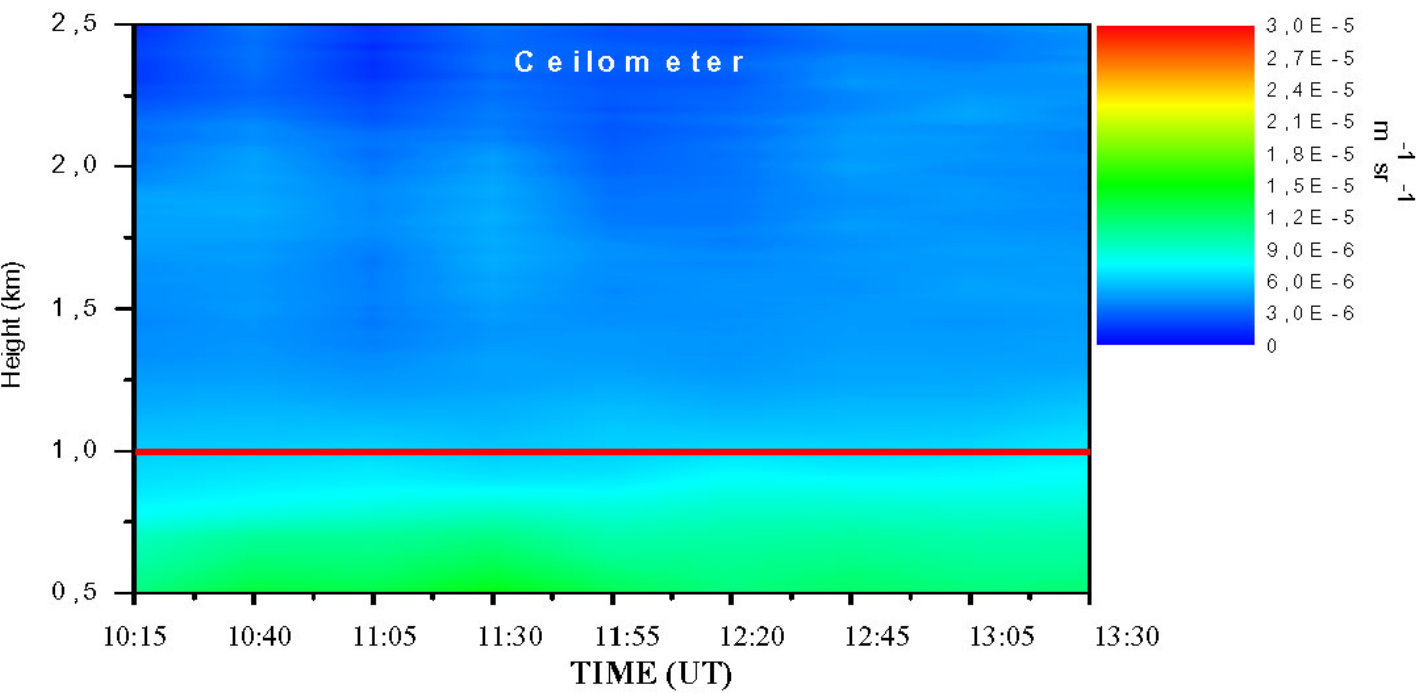

(b)

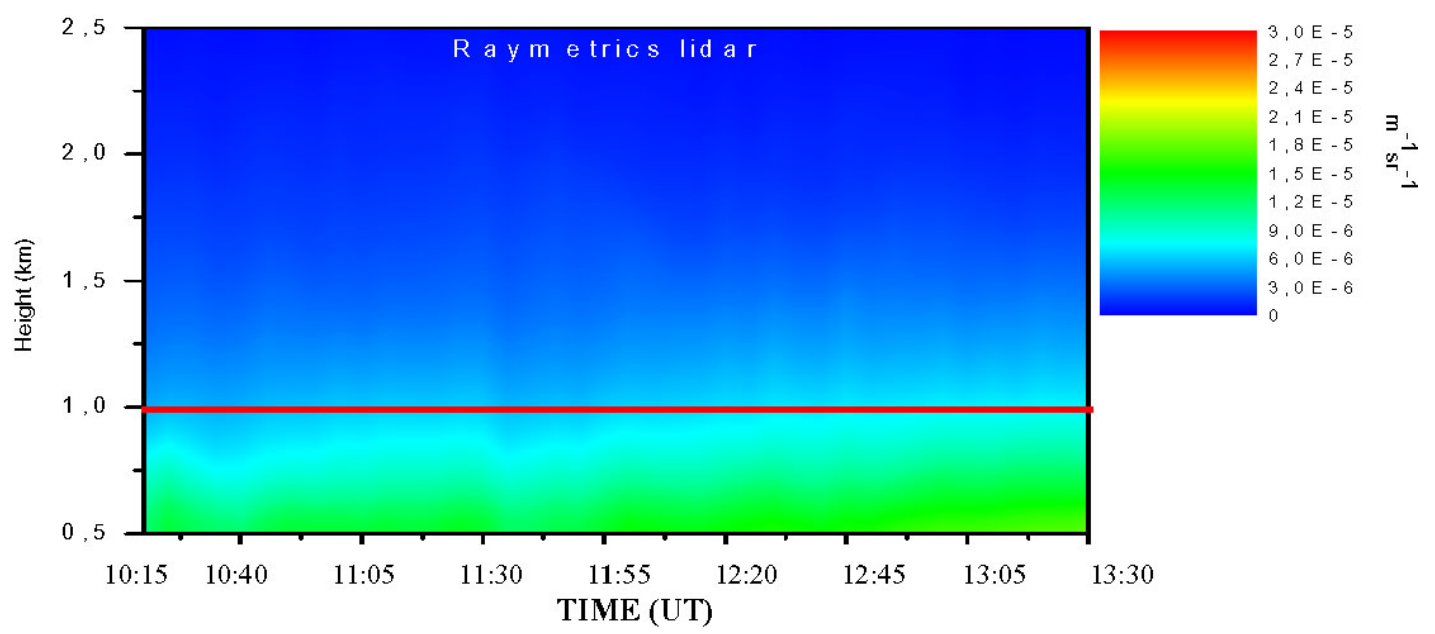

(c)

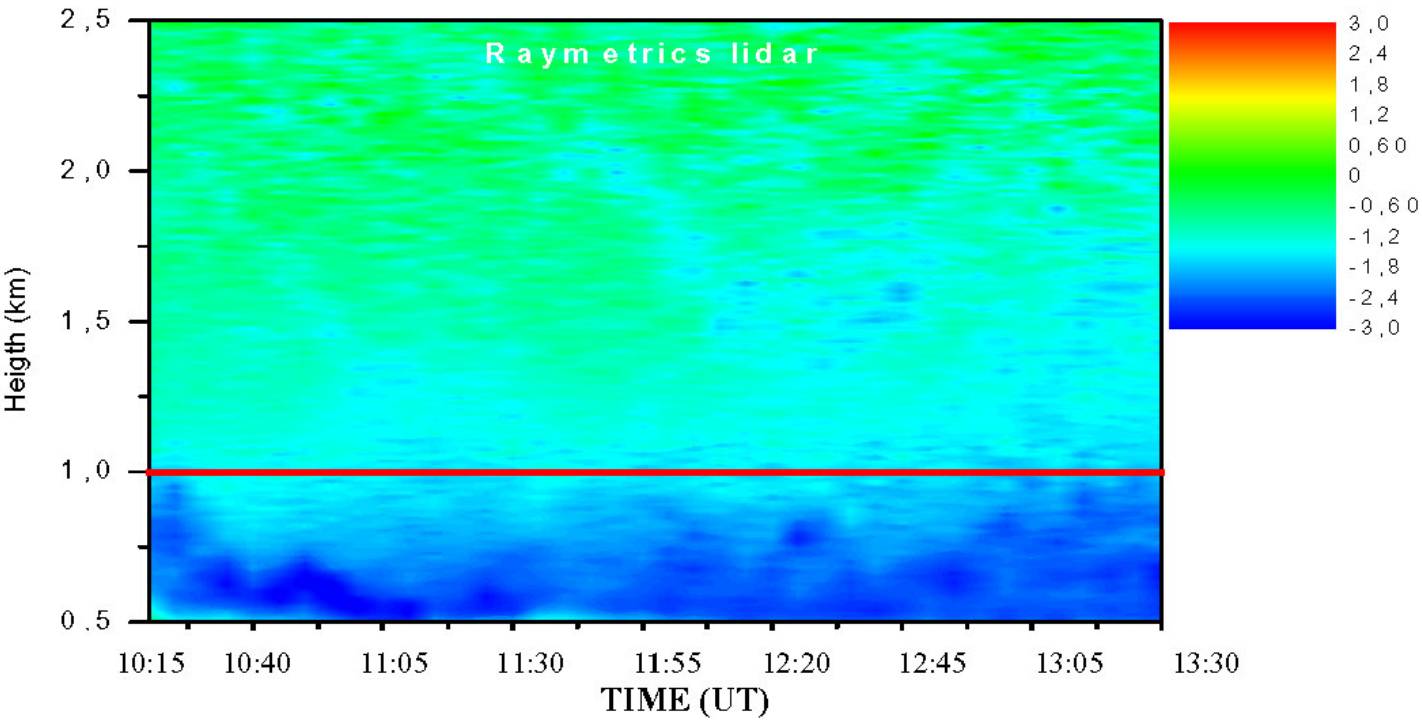

Fig. 1. Attenuated backscatter coefficient (in $\mathrm{m}^{-1} \mathrm{sr}^{-1}$ ) obtained (a) by the ceilometer and (b) the Raymetrics lidar. (c) The first derivative of the logarithm of the range-corrected lidar signal (in arbitrary units: A.U.) obtained by the Raymetrics system. Time height cross sections are valid from 10:15 UT to 13:30 UT on 26 November 2008. Red lines represent mean PBL height around 12:00 UT. 
(a)

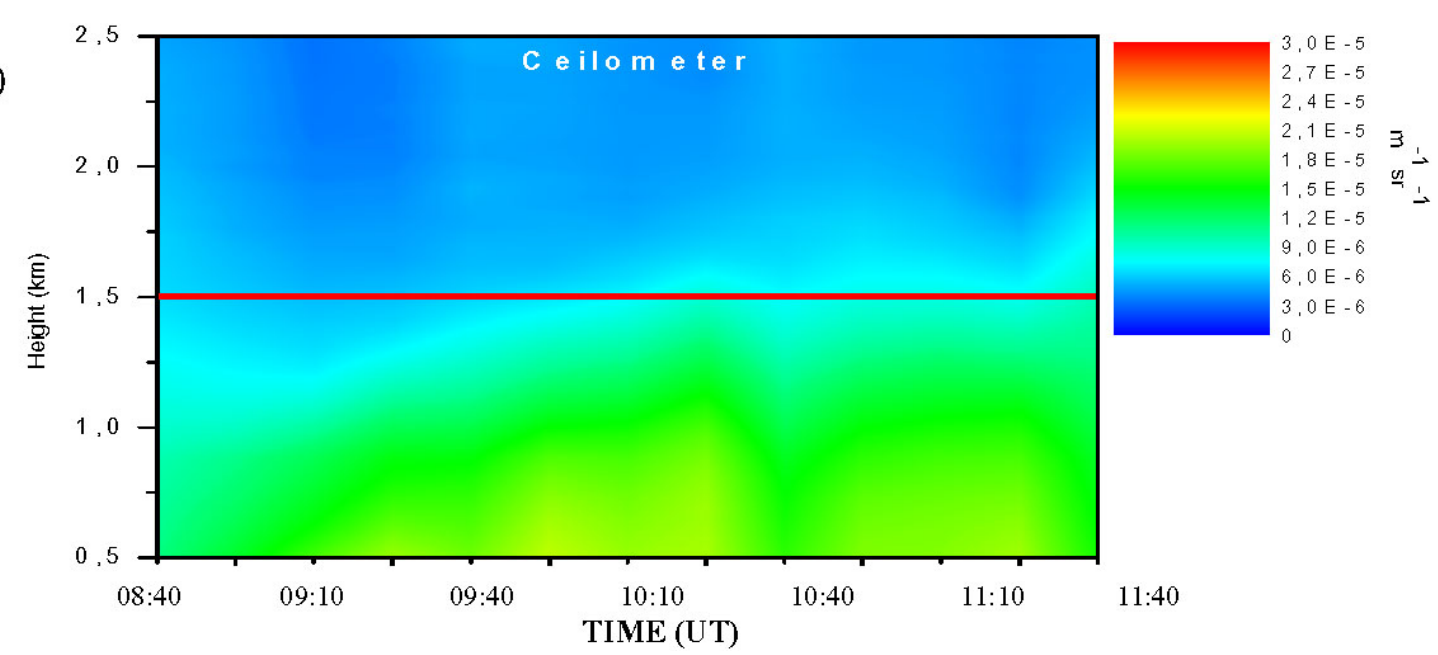

(b)

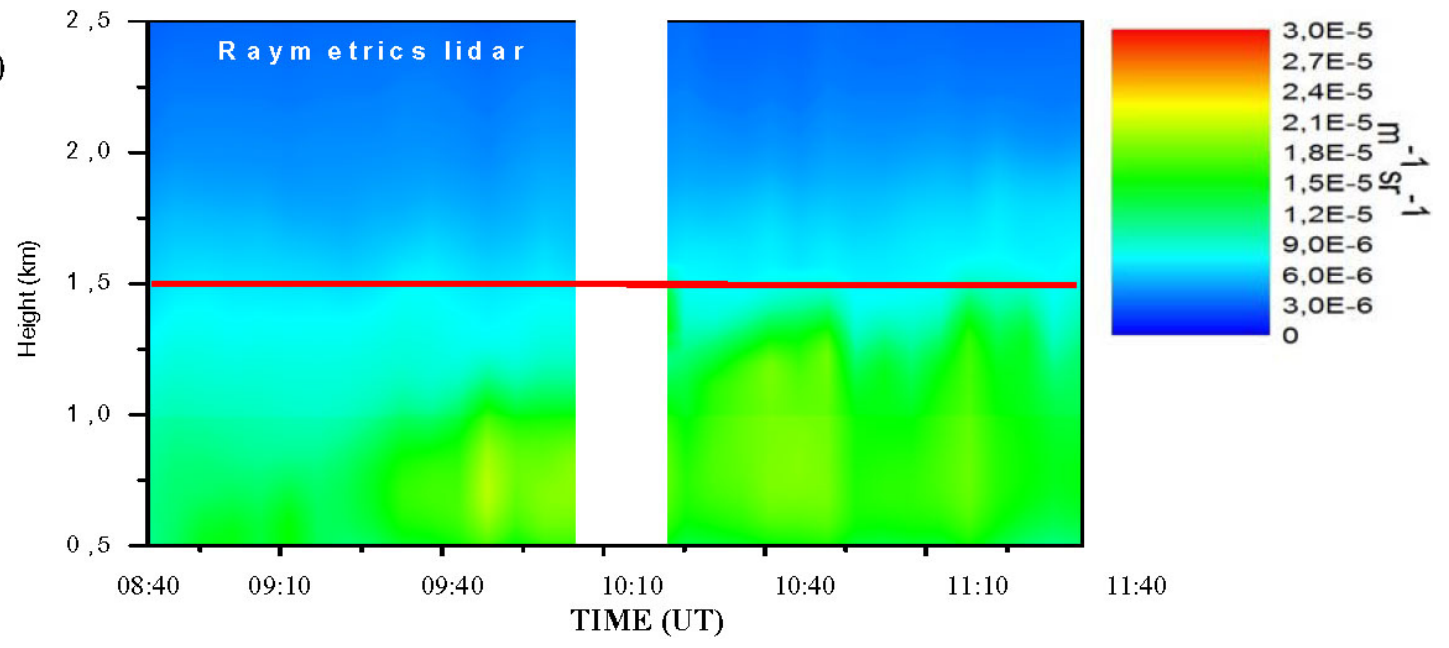

(c)

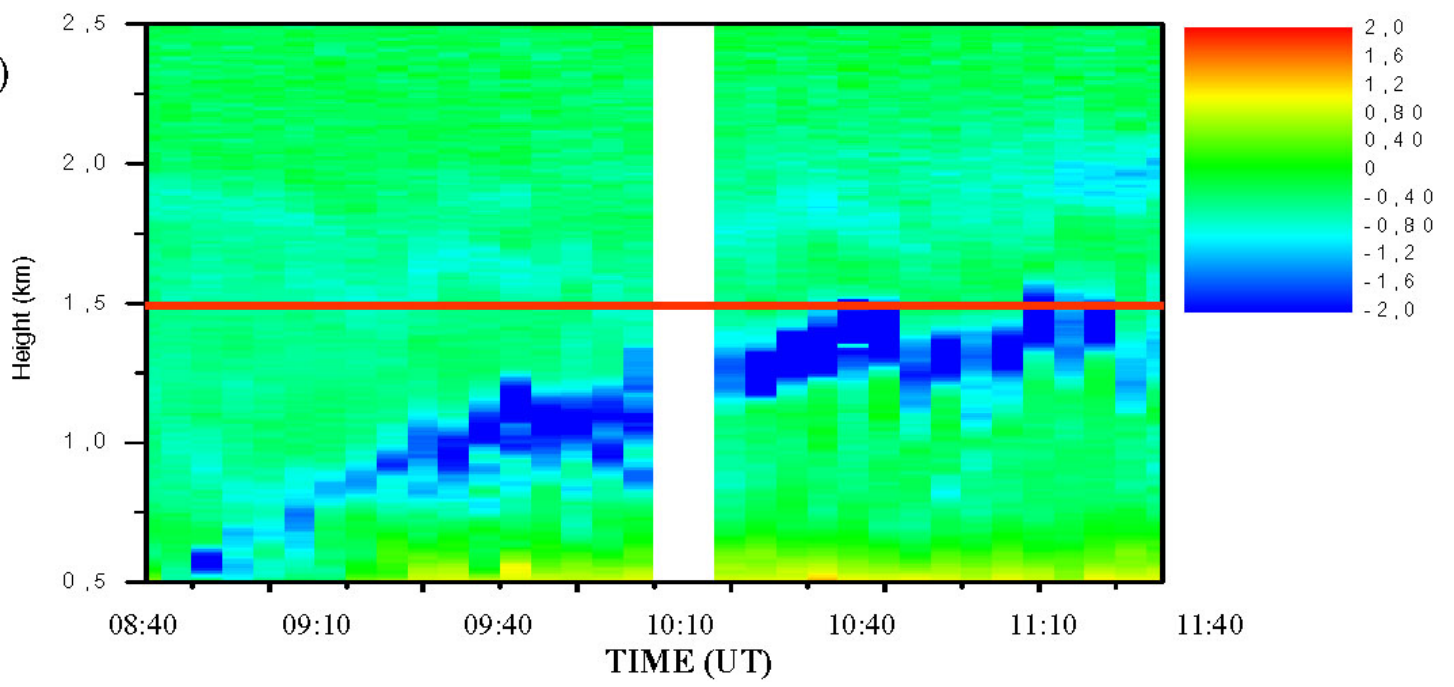

Fig. 2. Attenuated backscatter coefficient (in $\mathrm{m}^{-1} \mathrm{sr}^{-1}$ ) obtained (a) by the ceilometer and (b) the Raymetrics lidar. (c) The first derivative of the logarithm of the range-corrected lidar signal (in arbitrary units: A.U.) obtained by the Raymetrics system. Time height cross sections are valid from 08:40 UT to 11:40 UT on 27 November 2008. Red lines represent mean PBL height around 11:00 UT. 
The main goal of the Vaisala CL31 ceilometer is to report on the attenuated backscatter coefficient profiles, as well as cloud base and mixing height in the lower troposphere. The Quality Assurance procedure and the uncertainties (based on statistics) of the parameters provided by the CL31 ceilometer are discussed in Münkel et al. (2007). In brief, the average uncertainty on the retrieval of the attenuated backscatter coefficient when using the CL31 ceilometer data averaged over $30 \mathrm{~min}$ is of the order of $20 \%$ (Table 1; Münkel et al., 2007). In our study, the raw ceilometers' data are averaged with a 10-min time window to increase the signal to noise ratio (SNR) over a threshold of 1.

\subsection{Lidar systems}

The Raymetrics S.A. lidar system is a portable eye-safe elastic backscatter lidar system, fully automated. It can work $24 \mathrm{~h}$ per day outdoors in an unattended mode under almost any weather conditions. A pulsed laser beam at $355 \mathrm{~nm}$ is emitted into the atmosphere. The energy per emitted pulse is $40 \mathrm{~mJ}$, while the pulse duration is $10 \mathrm{~ns}$. A beam expander is used at the emission unit in order to expand the laser beam by a factor of 10 , so that the eye safety is completely fulfilled. The repetition rate is $10 \mathrm{~Hz}$. The backscattered radiation is collected by a Cassegrain telescope of $200 \mathrm{~mm}$ in diameter and having an f-number of 4 (focal length $f=800 \mathrm{~mm}$ ). The collected radiation is spectrally analyzed (using beam splitters), filtered (using narrow band interference filters) and focused on photomultiplier tubes (PMTs) which are used to detect the received lidar signals in the analog and the photon counting mode. The corresponding raw signal spatial resolution is $3.75 \mathrm{~m}$. For this study the raw temporal resolution of the retrieved aerosol profiles was set at $1.5 \mathrm{~min}$, while a spatial resolution of $7.5 \mathrm{~m}$ was used (Table 1). The retrieved averaged aerosol parameters profiles (attenuated and aerosol backscatter profiles) are shown every $10 \mathrm{~min}$. The full overlap height of the instrument is achieved for altitudes higher than $200 \mathrm{~m}$ (Table 1).

The NTUA lidar system is a multi-wavelength Raman lidar based on a compact pulsed Nd:YAG laser, emitting simultaneously at 355, 532 and $1064 \mathrm{~nm}$ with output laserbeam energies of 75,150 and $400 \mathrm{~mJ}$ per pulse, respectively. The repetition rate is $10 \mathrm{~Hz}$, while the pulse duration is $5 \mathrm{~ns}$. The optical receiver is a Cassegrain-reflecting telescope with a primary mirror of $300 \mathrm{~mm}$ in diameter and a focal length $\mathrm{f}=600 \mathrm{~mm}$, directly coupled, through an optical fiber, to the lidar signal detection unit (Mamouri et al., 2007). The lidar signals are detected with photomultiplier tubes (PMTs) operating both in the analog and photon-counting mode. The corresponding spatial resolution of the detected raw signals is $7.5 \mathrm{~m}$. The NTUA lidar detects both elastic backscattered (at 1064, 532, $355 \mathrm{~nm}$ ) and Raman (at 607 and $387 \mathrm{~nm}$-nitrogen and $407 \mathrm{~nm}$-water vapor) signals. The lidar operates in the frame of EARLINET network since 2000, and can provide continuous measurements of the aerosol backscatter verti- cal profiles ranging from $1000 \mathrm{~m}$ up to $15000 \mathrm{~m}$ height. For this study the raw temporal resolution of the retrieved aerosol profiles was set at $1.5 \mathrm{~min}$, while a spatial resolution of $15 \mathrm{~m}$ was used. The retrieved averaged aerosol parameters profiles (attenuated and aerosol backscatter profiles) are shown every $10 \mathrm{~min}$. The full overlap height of the instrument is achieved for altitudes higher than $1000 \mathrm{~m}$ (Table 1).

The Quality Assurance of the retrieved aerosol profiles by the NTUA lidar system has been evaluated in the frame of the EARLINET project by performing direct inter-comparisons, both at hardware and software levels, with a reference lidar system (Böckmann et al., 2004; Matthias et al., 2004; Pappalardo et al., 2004). The resulting average uncertainty on the retrieval of aerosol backscatter coefficient when using the NTUA and Raymetrics lidars (including both statistical and systematic errors and corresponding to at least 30$60 \mathrm{~min}$. temporal resolution) in the troposphere is based on the methodology described by Bösenberg et al. (1997) and is of the order of $20-30 \%$ (Table 1). The choice of the reference height for the Klett aerosol backscatter coefficient at wavelength $\lambda\left(b_{\lambda}\right)$ retrievals in the case of the lidar signals was set at $7 \mathrm{~km}$, since the signal to noise ratio (SNR) is still quite high even during daytime (higher than 1, according to our SNR calculations based on Heese et al. (2010), for averaging time over more than $30 \mathrm{~min}$ ). For the lidar signals in Athens, the lidar returns are first corrected for background light and range. The range-corrected signal return for the molecular atmosphere is then estimated using radiosonde data. The lidar range-corrected signal is then normalized on the molecular return to check for calibration and find the total attenuated backscatter signal. Through this procedure, the aerosol-free tropospheric region is defined as the region where the total attenuated backscatter coefficient is equal to the molecular attenuated backscatter signal. This region for Athens is usual above $6-7 \mathrm{~km}$.

\subsection{Multi Filter Radiometer}

The ultraviolet Multi Filter Radiometer (UV-MFR) measures the total, diffuse and direct solar radiation. The spectral measurements are performed in 6 wavelengths and a wide-band channel. The total and the diffuse radiation are measured directly while the direct radiation is calculated as the difference between the two. The spectral width of the UV-MFR optical filters is $10 \mathrm{~nm}$ (FWHM) at 415, 500, 615, 671, 867, $940 \mathrm{~nm}$. The cosine response is $5 \%$ for zenith angles between $0^{\circ}$ and $80^{\circ}$. The instrument is designed to perform continuous measurements for external temperatures ranging from -30 to $+50^{\circ} \mathrm{C}$ since the electronics and the photodiodes are enclosed in a thermally controlled box. 

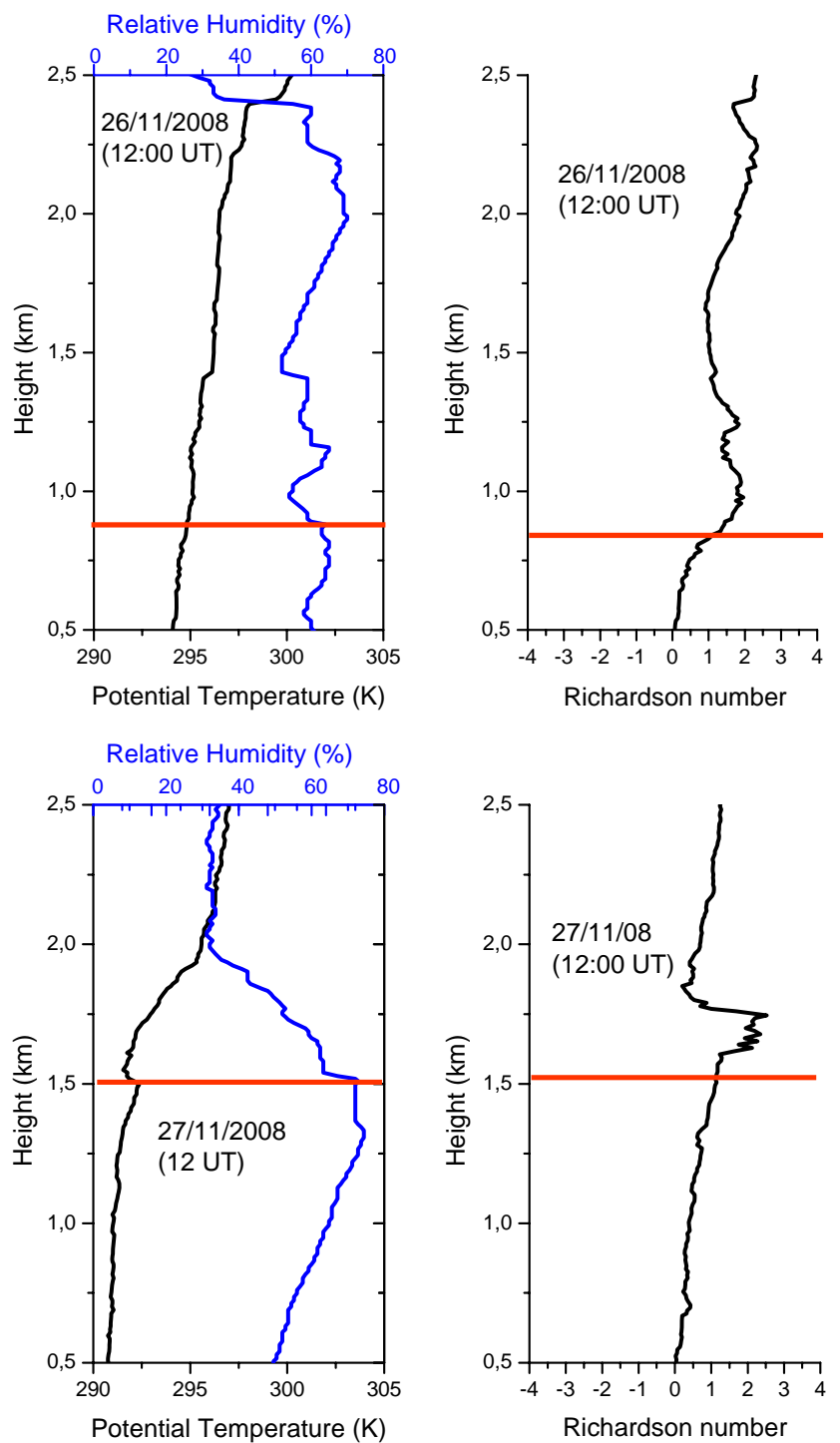

Fig. 3. Radiosonde data providing the vertical profile of the relative humidity (in \%), potential temperature (in K) (left side) and the Richardson number (right side), at 12:00 UT over Athens, on 26 November (a) and 27 November (b), 2008. The red lines indicate the PBL height.

\section{Inter-comparison of Planetary Boundary Layer height determination using ceilometer and lidar measurements}

The CL31 ceilometer and the Raymetrics lidar were combined and collocated for two days (26-27 November 2008) in order to perform measurements over Athens. Both instruments were located nearby the actinometrical station of the National Observatory of Athens (NOA) on the hill of Pnyx $\left(37.967^{\circ} \mathrm{N}, 23.717^{\circ} \mathrm{E}, 100 \mathrm{~m}\right.$ above sea level: a.s.l.). The ceilometer was operated on a 24-h basis, while the lidar for selected time periods within the above two days. All data are presented in Universal Time (UT).
In Fig. 1a we present the temporal evolution of the attenuated backscattered signal (in $\mathrm{m}^{-1} \mathrm{sr}^{-1}$ ) at $910 \mathrm{~nm}$ as obtained by the ceilometer on 26 November, between 10:15 and 13:30 UT, with a 10 min time resolution (based on $2 \mathrm{~s}$ raw time resolution signals), from $500 \mathrm{~m}$ to $2.5 \mathrm{~km}$. In Figs. $1 \mathrm{~b}$ and $\mathrm{c}$ we show the temporal evolution of the attenuated backscattered lidar signal and the corresponding first derivative of the logarithm of the range-corrected lidar signal at $355 \mathrm{~nm}$ (in Arbitrary Units: A.U.), respectively, as obtained by the Raymetrics lidar from 10:15 to 13:30 UT on the same day (the corresponding first derivative of the logarithm of the range-corrected ceilometer signal was not available). The same procedure was followed during the next day on 27 November, where simultaneous measurements were obtained from 08:40 to 11:40 UT (Figs. 2a, b and c). Along with the ceilometer and lidar soundings, radiosoundings were performed at a nearby location by the Hellenic National Meteorological Service (HNMS) at 12:00 UT to determine the PBL height. Figs. 3a and $b$ present the vertical profile of the relative humidity (in \%) and the potential temperature (in K) (left side), as well as the Richardson number $\left(R_{i}\right)$ (right side) calculated for 26 and 27 November 2008, respectively.

To retrieve the PBL height we used both radiosounding and lidar data, according to the methodologies provided by Stull (1988) and Menut et al. (1999), respectively. When radiosonde data are used to derive the PBL (or mixing) height, the strong negative gradient of the relative humidity, along with the positive gradient of the potential temperature, delineate the position of the PBL height. According to Joffre et al. (2001), the PBL height is identified by inspecting together the wind, humidity, potential temperature and $\mathrm{R}_{i}$ profiles for clear changes in the humidity profiles slope (Figs. 3a and $\mathrm{b}$ ), and/or persistent large departures of $\mathrm{R}_{i}$ values beyond a critical value of about 1 . In our case on 26 November at 12:00 UT, $\mathrm{R}_{i}$ clearly departs from around 1 at around $820 \mathrm{~m}$ height, which is close to the position (around $900 \mathrm{~m}$ ) of the first strong negative gradient of the relative humidity, along with the positive gradient of the potential temperature. On 27 November at 12:00 UT, $\mathrm{R}_{i}$ clearly departs from around 1 at around $1530 \mathrm{~m}$ height, which is very close to the position (around $1500 \mathrm{~m}$ ) of the first strong negative gradient of the relative humidity, along with the positive gradient of the potential temperature. In all graphs (Figs. 1, 2 and 3) the red lines indicate the PBL height.

In lidar research, it is customary to consider the PBL height as the height, below which most of the aerosol is confined, even if this layer is not always a well-mixed layer (e.g. Matthias and Bösenberg, 2002). Therefore, the determination of the PBL height from the lidar data is done by identifying the first significant negative gradient in the range-corrected lidar signal, starting from ground. The steep gradient in the range-corrected lidar signal results from the strong decrease in the aerosol (or the attenuated) backscatter caused by lower particle concentration and humidity above this height. The method is simple and it has been used since 

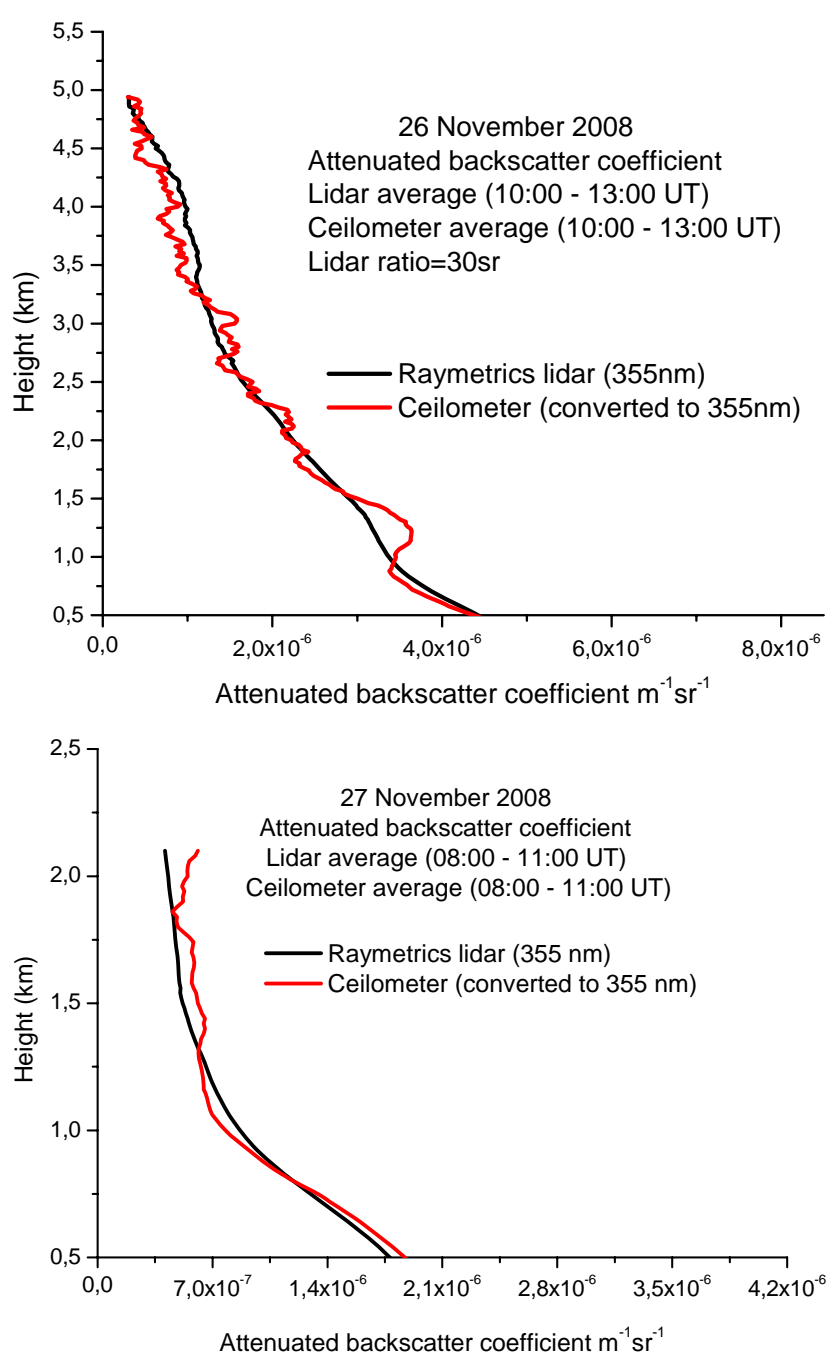

Fig. 4. Comparison of the attenuated backscatter coefficient profiles (in $\mathrm{m}^{-1} \mathrm{sr}^{-1}$ ) obtained by the Vaisala ceilometer and the Raymetrics lidar (a) on 26 November 2008 (10:00-13:00 UT) and (b) on 27 November 2008 (08:00-11:00 UT).

the '90s (e.g. Flamant et al., 1997; Menut et al., 1999).

When only the attenuated backscatter coefficient data are available (as in the case of the ceilometer data) we can still derive the PBL height, since its maximum height is very frequently associated with a strong gradient in the vertical aerosol profile (Endlich et al., 1979; Menut et al., 1999). Of course there are discrepancies between the lidar/ceilometer and radiosonde derived $\mathrm{PBL}$ height due to the fact that the thermodynamically defined PBL is not usually confined with the height of the well-mixed layer, as discussed by Joffre et al. (2001) and Hennemuth and Lammert (2006) and the references therein, as we will also see in the following.

According to the ceilometer and Raymetrics attenuated backscatter data (Figs. 1a and b) the PBL height on 26 November ranged between $0.75 \mathrm{~km}$ to $0.95 \mathrm{~km}$ a.s.l. (light blue color) and remained practically constant around $1 \mathrm{~km}$ after 12:00 UT, in good agreement with the PBL retrieved height from the radiosounding at 12:00 UT (Fig. 3a). The internal part of the PBL (Stull, 1988) is represented by the light green color structure, which is located around $0.7-0.8 \mathrm{~km}$. This becomes more visible in the temporal evolution of the first derivative of the logarithm of the range-corrected Raymetrics lidar signal (Fig. 1c) where the zones of dark blue colors delineate the PBL height (ranging from 800-1000 m). As a first conclusion, comparing the three graphs of Fig. 1a, $\mathrm{b}$ and $\mathrm{c}$, we can say that both systems revealed a very similar PBL structure (with a difference of about 50-100 m), when the same time period of measurements is considered, in accordance with the mean PBL height retrieved by the radiosounding at 12:00 UT (Fig. 3a). Next day's ceilometer's measurements (Fig. 2a) showed that the PBL height ranged from $800 \mathrm{~m}$ (around 09:00 UT) to $1500 \mathrm{~m}$ (from 10:40 UT to 11:40 UT) (light green color structure). The corresponding lidar measurements (Fig. 2b and c) showed that the PBL height ranged from $700 \mathrm{~m}$ (around 09:00 UT) to $1500 \mathrm{~m}$ (from 10:40 UT to 11:40 UT), which is a typical evolution of the PBL due to increased solar irradiance (Stull, 1998). This evolution is more clearly visible in Fig. 2c by the deep blue color scale structure. In this comparison of the two instruments, we see that both of them were able to retrieve the PBL height, with a difference of about 50-100 m, in accordance with the mean PBL height retrieved by the radiosounding at 12:00 UT (Fig. 3b).

\section{Inter-comparison of attenuated backscatter coefficients obtained by lidar and ceilometer measurements}

In this study we also compared the attenuated backscatter profiles obtained by the three laser remote sensors. The lidar system provided by Raymetrics S.A. was used as a reference system for comparing the vertical profiles of the attenuated backscatter coefficient. The main drawback of this inter-comparison was that the Raymetrics lidar and the CL31 ceilometer were running at two different wavelengths. The ceilometer operates in the infrared $(910 \mathrm{~nm})$, the Raymetrics lidar operates in the ultraviolet $(355 \mathrm{~nm})$, while the NTUA lidar data used are limited to the near infrared $(1064 \mathrm{~nm})$ region, which is quite closer to the ceilometer emission.

Since our goal is to compare the retrievals of both instruments, in terms of the attenuated backscatter coefficient and the mixing height, a spectral conversion (for the retrieval of the first parameter) is needed when different wavelengths are used. The conversion factor used is the backscatter-related Angström exponent, which is retrieved from the extinction-related Ångström exponent taken from multi-filter radiometer (MFR) measurements. Specifically, the backscatter-related Ångström exponent equals the extinction-related Ångström exponent, when the lidar ratio is assumed spectrally independent, according to the following 


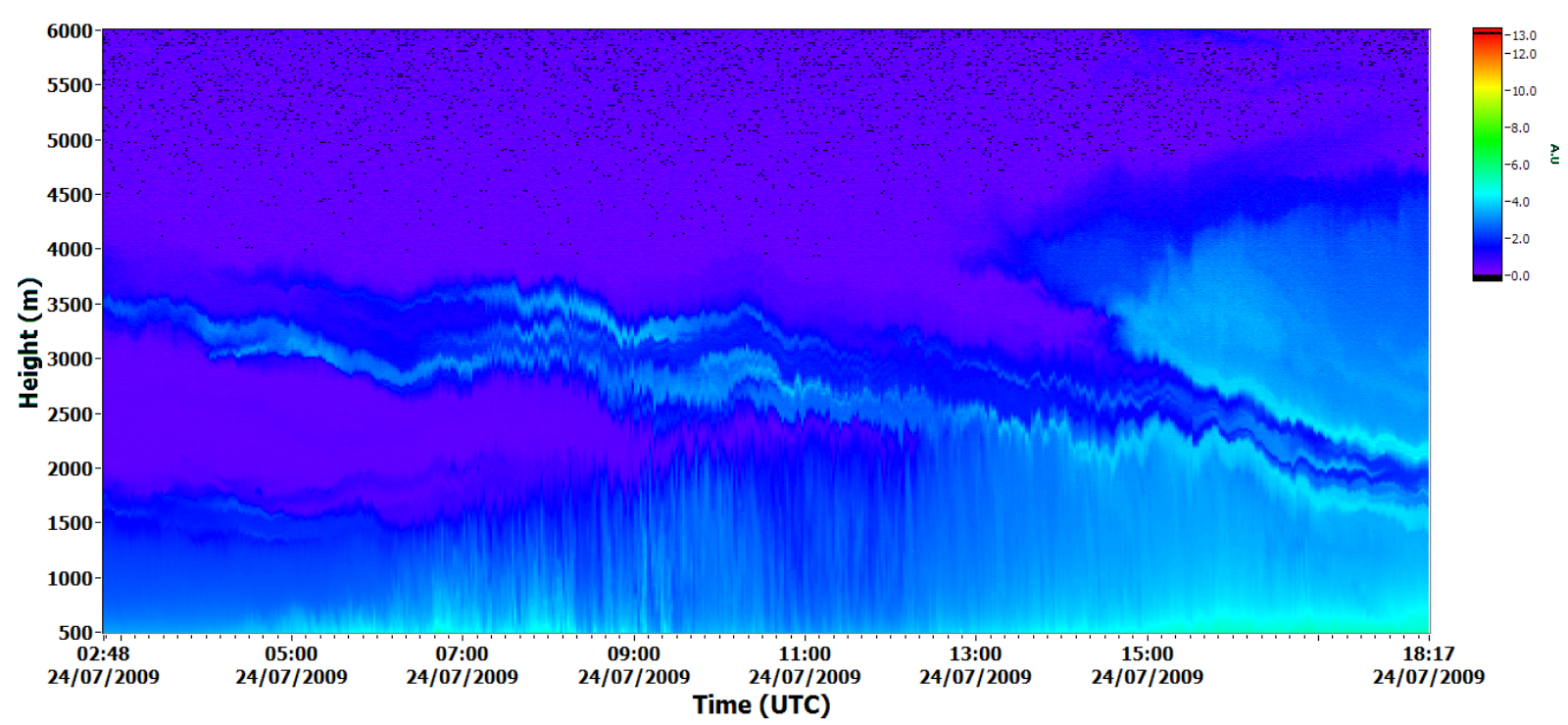

Fig. 5. Temporal evolution of the range-corrected lidar signal (in arbitrary units: A.U.) at 1064 nm as obtained by the NTUA Raman lidar system on 24 July 2009 (02:48-18:17 UT).
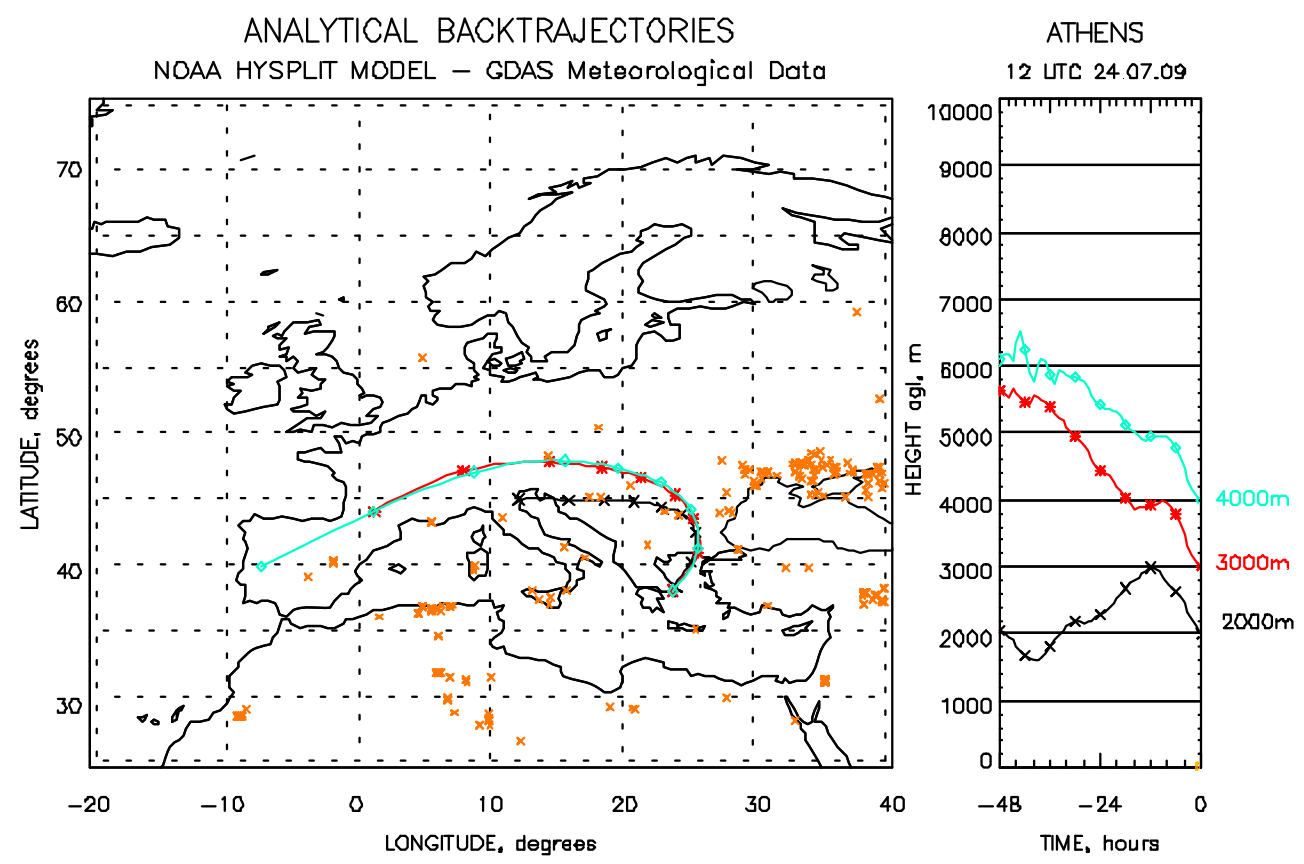

Fig. 6. Back-trajectories of air masses arriving over Athens on 24 July 2009 (12:00 UT) at various heights (2000 m, $3000 \mathrm{~m}, 4000 \mathrm{~m})$. The orange points indicate the active hot spots from biomass burning sites. Time step is $6 \mathrm{~h}$.

equations:

$C(z)=-\frac{\ln \left(\frac{\alpha_{\lambda_{1}}}{\alpha_{\lambda_{2}}}\right)}{\ln \left(\frac{\lambda_{1}}{\lambda_{2}}\right)}=-\frac{\ln \left(\frac{S_{\lambda_{1}} * b_{\lambda_{1}}}{S_{\lambda_{2}} * b_{\lambda_{2}}}\right)}{\ln \left(\frac{\lambda_{1}}{\lambda_{2}}\right)}=-\frac{\ln \left(\frac{S_{\lambda_{1}}}{S_{\lambda_{2}}}\right)}{\ln \left(\frac{\lambda_{1}}{\lambda_{2}}\right)}-\frac{\ln \left(\frac{b_{\lambda_{1}}}{b_{\lambda_{2}}}\right)}{\ln \left(\frac{\lambda_{1}}{\lambda_{2}}\right)}$

$\Leftrightarrow C(z)=-\frac{\ln \left(\frac{b_{\lambda_{1}}}{b_{\lambda_{2}}}\right)}{\ln \left(\frac{\lambda_{1}}{\lambda_{2}}\right)}$ where $c(z)$ is the backscatter or extinction-related Ångström exponent; $\alpha_{\lambda}, b_{\lambda}$ are the extinction and backscatter coefficients, respectively; $S_{\lambda}$ is the lidar ratio; $\lambda_{1}, \lambda_{2}$ are the emitted laser wavelengths (e.g. $\lambda_{1}=355$ or $1064 \mathrm{~nm}$, $\left.\lambda_{2}=910 \mathrm{~nm}\right)$.

Equation (1) leads to the following conversion:

$b_{\lambda_{1}}=e^{-\ln \left(\frac{\lambda_{1}}{\lambda_{2}}\right) \times c(z)} b_{\lambda_{2}}$ 


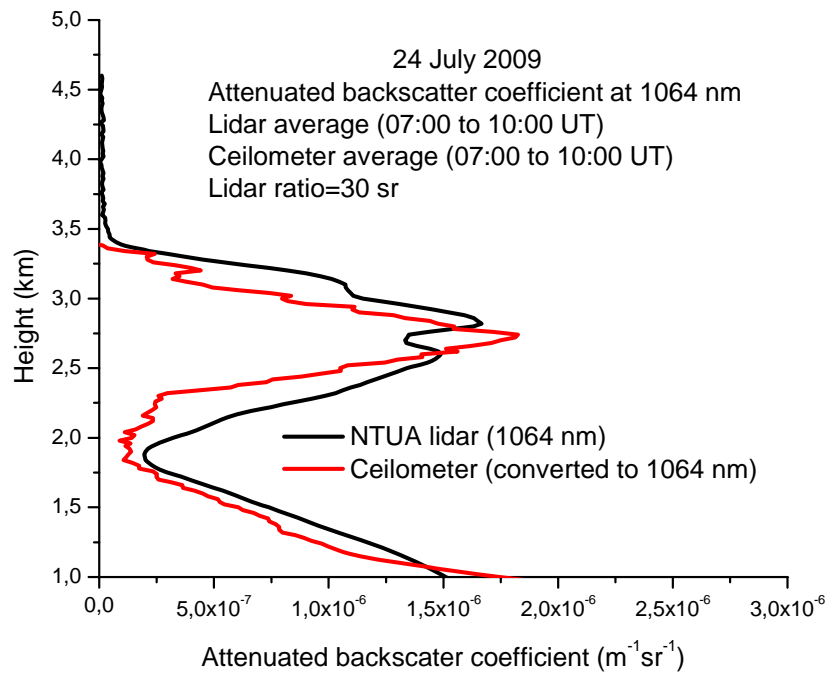

Fig. 7. Comparison of the attenuated backscatter coefficient profiles (in $\mathrm{m}^{-1} \mathrm{sr}^{-1}$ ) obtained by the Vaisala ceilometer and NTUA Raman lidar system (07:00-10:00 UT) on 24 July 2009.

where $b_{\lambda 1}$ and $b_{\lambda 2}$ are the corresponding aerosol backscatter coefficients at altitude $z$.

The calculated values of the extinction-related Ångström exponent (Michalsky et al., 2001) for the days into consideration using measurements of the aerosol optical depth (AOD) obtained by the UV-MFR radiometer were found to be 1.98 for 26 November 2008 and 0.37 for 27 November 2008. The lidar ratio for CL31's aerosol backscatter retrievals is assumed by default to be equal to $30 \mathrm{sr}$ (Vaisala User's Guide, 2009), and this assumption is followed also for lidar calculations in order to have more comparable aerosol vertical profiles.

In Fig. $4 \mathrm{a}$ and $\mathrm{b}$ we present the results of the comparison of the attenuated backscatter coefficient profiles obtained by the Raymetrics lidar (at $355 \mathrm{~nm}$ ) and CL31 ceilometer (converted to $355 \mathrm{~nm}$ data) instruments for 26 and 27 November. Since the ceilometer's output energy is low we had to perform a 3-h average (08:00-11:00 UT) in order to sufficiently reduce the noise in the attenuated backscatter coefficient profiles obtained by the instrument. This method was followed in all the ceilometer attenuated backscatter coefficient profiles presented in this study. For the lidar measurements we also averaged $3 \mathrm{~h}$ profiles, as shown in Fig. $4 \mathrm{a}$ and $\mathrm{b}$. The corresponding range resolution of the retrieved attenuated backscatter profile for both systems was set to $30 \mathrm{~m}$.

From Fig. 4a and b, we see that the comparison of the retrieved attenuated backscatter vertical profiles converted to $355 \mathrm{~nm}$, by both systems, is quite satisfactory from $0.5 \mathrm{~km}$ up to $5 \mathrm{~km}$ height a.s.l. (26 November) and from $0.5 \mathrm{~km}$ up to $2.5 \mathrm{~km}$ height a.s.1. (27 November). The mean differences in the retrieved values remain less than 10-15\%. In the following section we present an inter-comparison analysis between the NTUA and the ceilometer retrieved vertical attenuated backscattered profiles obtained during two different aerosol conditions over Athens (biomass burning smoke and Saharan dust event).

\subsection{Case studies}

\subsubsection{Forest fire (biomass burning) smoke aerosols}

On 24 July 2009 during scheduled measurements within EARLINET, an intense aerosol layer was detected by the NTUA Raman lidar system $\left(37.96^{\circ} \mathrm{N}, 23.78^{\circ} \mathrm{E}\right.$, $212 \mathrm{~m}$ a.s.l.). In Fig. 5 we present the temporal evolution of the range-corrected lidar signal obtained at $1064 \mathrm{~nm}$. This layer (about $0.5-1 \mathrm{~km}$ thickness) appeared over Athens at an altitude of $3.5 \mathrm{~km}$ (around 02:40 UT) and started to descend during the night, merging with the convective PBL located around $2.2 \mathrm{~km}$ at about 12:00 UT on the following day. According to the Hysplit model (Draxler and Rolph, 2003), the origin of the air masses arriving over Athens at various levels $(2 \mathrm{~km}, 3 \mathrm{~km}$ and $4 \mathrm{~km})$ at 12:00 UT on that day (shown in Fig. 6, with a time step of $6 \mathrm{~h}$ ) overpassed the Balkan area, only one day earlier. It seems that these air masses were enriched by smoke particles emitted from forest fires in Romania, as corroborated by the corresponding ESA/ATSR data (the orange points indicating the active hot spots from biomass burning sites), also shown in Fig. 6 .

Figure 7 shows the averaged vertical profiles of the attenuated backscatter coefficient obtained by the NTUA Raman lidar (at $1064 \mathrm{~nm}$ ) and the ceilometer (converted to $1064 \mathrm{~nm}$ data), both averaged on $3 \mathrm{~h}(07: 00-10: 00 \mathrm{UT})$ and retrieved with the same vertical range resolution $(30 \mathrm{~m})$. As shown in Fig. 7, both instruments recorded on 24 July a very intense aerosol layer over Athens extending from $2 \mathrm{~km}$ up to $3.5 \mathrm{~km}$. The backscatter-related Ångström exponent value used for the wavelength conversion of the ceilometer backscatter coefficient profile from $910 \mathrm{~nm}$ to $1064 \mathrm{~nm}$ was found to be 1.59 and was calculated from MFR data following the methodology described previously. The maximum value of the attenuated backscatter coefficient within this layer was quite close for both systems and ranged between $1.5 \times 10^{-6} \mathrm{~m}^{-1} \mathrm{sr}^{-1}$ and $1.85 \times 10^{-6} \mathrm{~m}^{-1} \mathrm{sr}^{-1}$. In any case, the mean difference between the two vertical profiles was not higher than $25 \%$. This difference can be attributed to the fact that the two systems were not collocated, since the ceilometer was located on the Pnyx hill, while the lidar was located inside the NTUA Campus at a distance of $6 \mathrm{~km}$.

\subsubsection{Desert dust aerosols}

On 1 June 2009, the NTUA Raman lidar system detected several aerosol layers over Athens. In Fig. 8 we present the temporal evolution of the range-corrected lidar signal (in A.U.) at $1064 \mathrm{~nm}$ as obtained by the NTUA Raman lidar system on that day between 12:02-13:19 UT. In this figure we can see that two strong and stable layers were detected around $2 \mathrm{~km}$ 


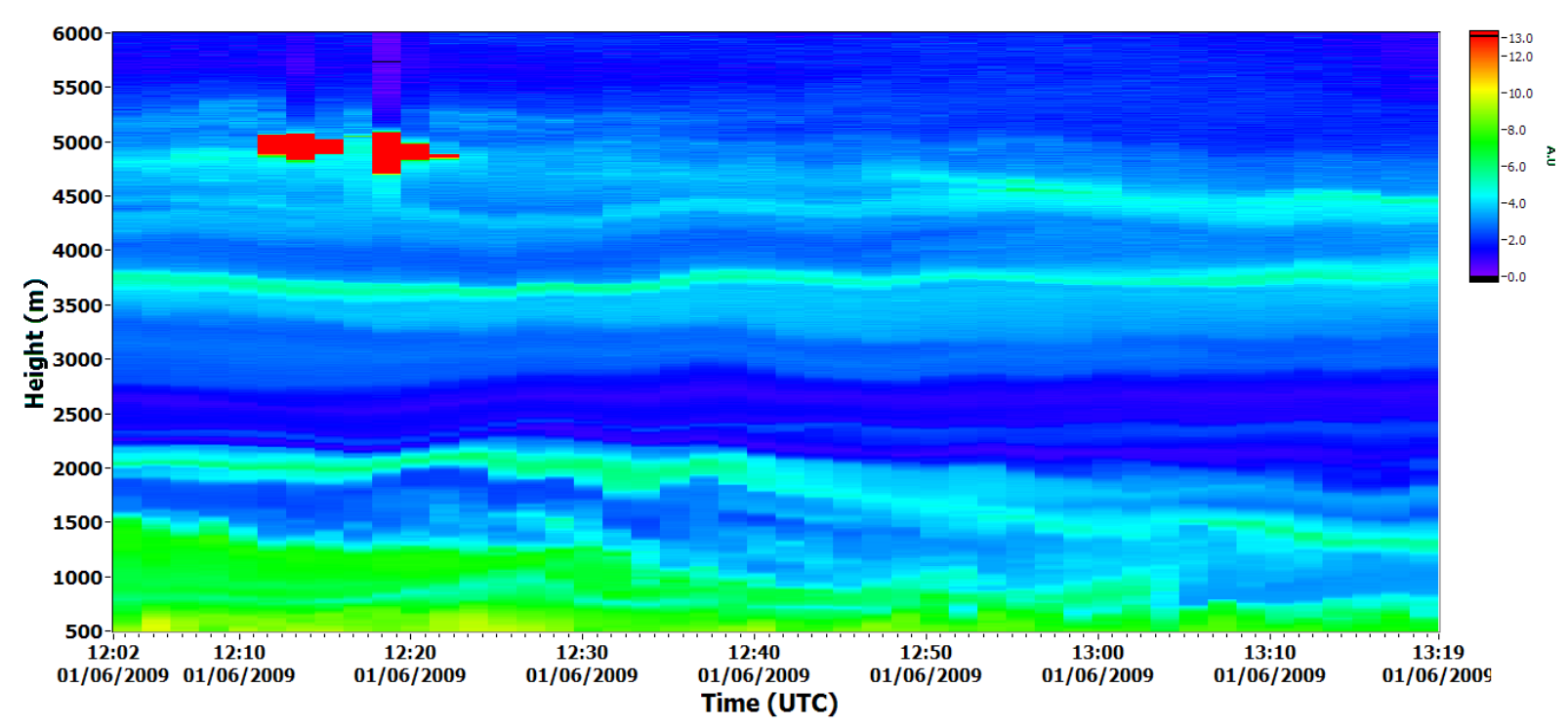

Fig. 8. Temporal evolution of the range-corrected lidar signal (in arbitrary units: A.U.) at $1064 \mathrm{~nm}$ as obtained by the NTUA Raman lidar system on 1 June 2009 (12:02-13:19 UT).
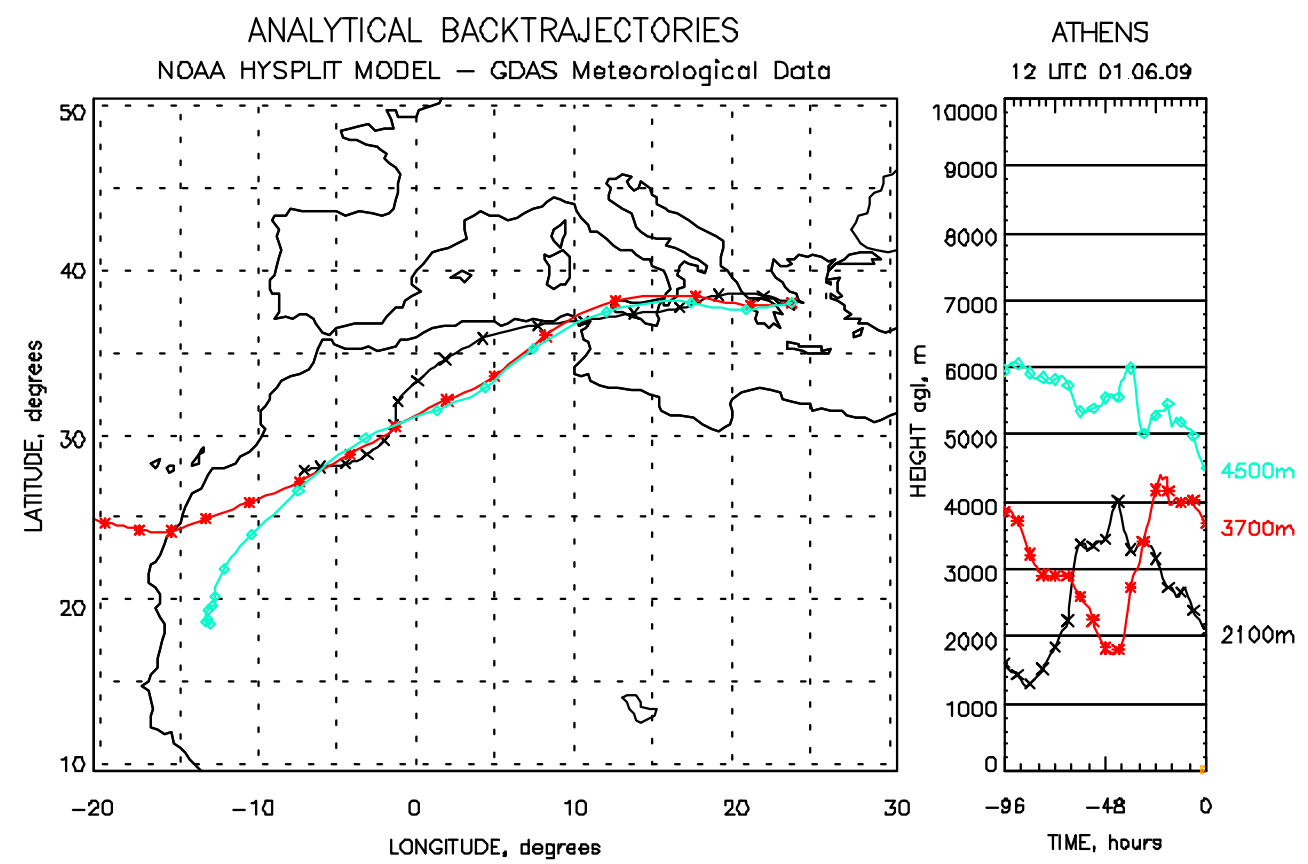

Fig. 9. Back-trajectories of air masses arriving over Athens on 1 June 2009 (12:00 UT) at various heights (2100 m, $3700 \mathrm{~m}, 4500 \mathrm{~m})$. Time step is $6 \mathrm{~h}$.

and $3.75 \mathrm{~km}$, while less intense layers were found around $4.5 \mathrm{~km}$ and $5 \mathrm{~km}$. We can also observe that the aerosol layer around $2 \mathrm{~km}$ merges with the convective PBL around 13:00 UT. On that day the CL31 ceilometer performed simultaneous measurements with the NTUA Raman lidar system. To identify the origin of the air masses sampled over Athens, we used the Hysplit model with a time step of $6 \mathrm{~h}$ (Fig. 9). The 4-day air mass back-trajectories showed that the origin of the particles detected over Athens was the Central and Western Saharan deserts, which indicates the advection of dust.

In Fig. 10 we examine the corresponding attenuated backscatter coefficient profiles obtained by the two instruments and averaged over two hours period (11:0013:00 UT). The corresponding range resolution of the retrieved attenuated backscatter profile for both systems was 


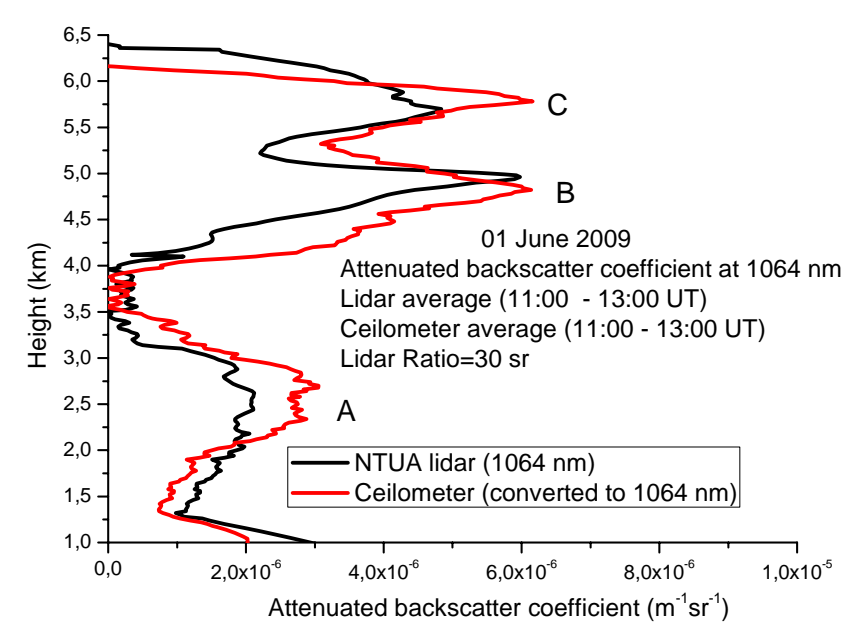

Fig. 10. Comparison of the attenuated backscatter coefficient profiles (in $\mathrm{m}^{-1} \mathrm{sr}^{-1}$ ) obtained by the Vaisala ceilometer and the NTUA Raman lidar system (11:00-13:00 UT) on 1 June 2009.

set to $30 \mathrm{~m}$. The ceilometer vertical profile of the attenuated backscatter coefficient obtained originally at $910 \mathrm{~nm}$ was converted to the wavelength of the NTUA lidar $(1064 \mathrm{~nm})$ according to Eq. (2). The backscatter-related Ångström exponent used for the calculation was 0.88 and was found using the AOD data obtained by the MFR radiometer (at $416 \mathrm{~nm}$ and $940 \mathrm{~nm}$ ). As it can be observed in Fig. 10, the aerosol layers were recorded by both instruments and were generally in good agreement. At the peak of the layer A (around $2-3 \mathrm{~km}$ ) the values of the attenuated backscatter coefficient measured by the two instruments differed by about $1 \times 10^{-6}\left(\mathrm{~m}^{-1} \mathrm{sr}^{-1}\right)$. As in layer A, the ceilometer retrievals for layers $B$ and $C$ showed, generally, higher values than the ones obtained by the lidar system. For layer B, the peak values obtained by the ceilometer and the lidar were almost identical (around $6 \times 10^{-6} \mathrm{~m}^{-1} \mathrm{sr}^{-1}$ ) at $4.8-5 \mathrm{~km}$. Layer $\mathrm{C}$ was lying at around $5.6-5.7 \mathrm{~km}$ and the corresponding values of the ceilometer and the lidar were $6.1 \times 10^{-6}\left(\mathrm{~m}^{-1} \mathrm{sr}^{-1}\right)$ and $5 \times 10^{-6}\left(\mathrm{~m}^{-1} \mathrm{sr}^{-1}\right)$, respectively. As can be seen in Fig. 10, the ceilometer shows higher values of the attenuated backscatter coefficient both at layer C (around 22\%) and at layer A (around $50 \%$ ). This difference can be attributed to the $6 \mathrm{~km}$ distance between the two sounding sites, which may play a certain role regarding the sampling of eventually different air masses. However, the mean difference between the measured aerosol profiles by both instruments, in terms of the attenuated backscatter coefficient, remains of the order of about $10-20 \%$.

\section{Summary and conclusions}

In this paper we showed the inter-comparison of two active remote sensors (lidar and ceilometer) in determining the structure of the PBL and in retrieving the tropospheric aerosol vertical profiles over Athens, Greece. This was performed under strongly different atmospheric conditions (urban air pollution, biomass burning and Saharan dust event). We showed that in general a good agreement was found in determining these two parameters, especially when collocated measurements were performed (a difference of about $50-100 \mathrm{~m}$ in retrieving the PBL height and about $10-25 \%$ in the case of the attenuated backscatter coefficients intercomparison). This difference may be attributed mainly to an unsatisfactory retrieval of the backscatter-related Ångström exponent when data are converted from the near infrared to the ultraviolet region and also in the distance between the ceilometer and NTUA lidar instruments in case of noncollocated measurements. It was also found that the Vaisala CL31 ceilometer was able to detect correctly the presence of various aerosol layers up to a height of $6 \mathrm{~km}$ a.s.l. (during daytime with $3 \mathrm{~h}$ averaging time), under strongly different aerosol concentrations (urban air pollution, biomass burning and intense Saharan dust event).

Acknowledgements. The Hellenic National Meteorological Service (HNMS) is gratefully acknowledged for the provision of the radiosonde data. The authors gratefully acknowledge the NOAA Air Resources Laboratory (ARL) for the provision of the HYSPLIT transport and dispersion model and/or READY website (http://www.arl.noaa.gov/ready.php) used in this publication. Hot spot fire data were provided by the ATSR/ESA satellite. The authors would like also to thank the reviewers and the Editor for their helpful comments.

Edited by: C. Senff

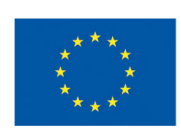

European Union European Union
European Social Fund

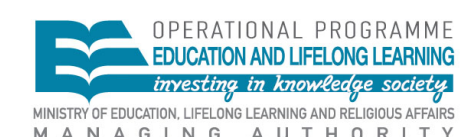
MANAGINGA A THORITY

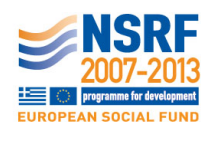

This research has been co-financed by the European Union (European Social Fund - ESF) and Greek national funds through the Operational Program "Education and Lifelong Learning" of the National Strategic Reference Framework (NSRF) - Research Funding Program: Heracleitus II. Investing in knowledge society through the European Social Fund.

\section{References}

Amiridis, V., Balis, D. S., Kazadzis, S., Giannakaki, E., Papayannis, A., and Zerefos, C.: Four-year aerosol observations with a Raman lidar at Thessaloniki, Greece, in the framework of EARLINET, J. Geophys. Res., 110, D21203, doi:10.1029/2005JD006190, 2005.

Amiridis, V., Melas, D., Balis, D. S., Papayannis, A., Founda, D., Katragkou, E., Giannakaki, E., Mamouri, R. E., Gerasopoulos, E., and Zerefos, C.: Aerosol Lidar observations and model calculations of the Planetary Boundary Layer evolution over Greece, 
during the March 2006 Total Solar Eclipse, Atmos. Chem. Phys., 7, 6181-6189, doi:10.5194/acp-7-6181-2007, 2007.

Amiridis, V., Balis, D. S., Giannakaki, E., Stohl, A., Kazadzis, S., Koukouli, M. E., and Zanis, P.: Optical characteristics of biomass burning aerosols over Southeastern Europe determined from UVRaman lidar measurements, Atmos. Chem. Phys., 9, 2431-2440, doi:10.5194/acp-9-2431-2009, 2009.

Angelou, N., Papayannis, A., Mamouri, R. E., Amiridis, V., and Tsaknakis, G.: On the relation between aerosol backscatter and atmospheric relative humidity in an urban area over Athens, Greece by using Raman lidar and radiosonde data, Int. J. Rem. Sensing, in press, 2011.

Böckmann, C., Wandinger, U., Ansmann, A., Bösenberg, J., Amiridis, V., Boselli, A., Delaval, A., De Tomasi, F., Frioud, M., Grigorov, I., Hagard, A., Horvat, M., Iarlori, M., Komguem, L., Kreipl, S., Larcheveque, G., Matthias, V., Papayannis, A., Pappalardo, G., Rocadenbosch, F., Rodrigues, J. A., Schneider, J., Shcherbakov, V., and Wiegner, M.: Aerosol lidar intercomparison in the framework of the EARLINET project: Part II - Aerosol backscatter algorithms, Appl. Opt., 43, 977-989, 2004.

Bösenberg, J., Timm, R., and Wulfmeyer, V.: Study of retrieval algorithms for a backscatter lidar, Final Report, MPI Report No. 226, Hamburg, 1-66, 1997.

Draxler, R. R. and Rolph, G. D.: HYSPLIT (HYbrid Single-Particle Lagrangian Integrated Trajectory) Model Access via NOAA ARL READY Website. NOAA Air Resources Laboratory, Silver Spring, MD, 2003.

Emeis, S., Schafer, K., and Münkel, C.: Longterm observations of the urban mixing-layer height with ceilometers. - IOP Conf. Series: Earth and Environ. Sci., 1, 012027, doi:10.1088/17551315/1/1/012027, 2008.

Endlich, R. M., Ludwig, F., and Uthe, E. E.: An automated method for determining the mixing layer depth from lidar observations, Atmos. Environ., 13, 1051-1056, 1979.

Eresmaa, N., Karppinen, A., Joffre, S. M., Rsnen, J., and Talvitie, H.: Mixing height determination by ceilometer, Atmos. Chem. Phys., 6, 1485-1493, doi:10.5194/acp-6-1485-2006, 2006.

Eresmaa, N., Härkönen, J., and Karppinen, A.: Boundary-Layer height estimated by ceilometer, Proceedings, The Seventh International Conference on Urban Climate, 29 June-3 July 2009, Yokohama, Japan, 2009.

Flamant, C., Pelon, J., Flamant, P., and Durand, P.: Lidar determination of the entrainment zone thickness at the top of the unstable marine atmospheric boundary layer, Boundary Layer Meteorol., 83, 247-284, 1997.

Heese, B., Flentje, H., Althausen, D., Ansmann, A., and Frey, S.: Ceilometer lidar comparison: backscatter coefficient retrieval and signal-to-noise ratio determination, Atmos. Meas. Tech., 3, 1763-1770, doi:10.5194/amt-3-1763-2010, 2010.

Hennemuth, B. and Lammert, A.: Determination of the Atmospheric Boundary Layer height from radiosonde and lidar backscatter, Boundary Layer Meteorol., 120, 181-200, 2006.

Joffre, S., Kangas, M., Heikinheimo, M., and Kitaigorodskii, S. A.: Variability of the stable and unstable atmospheric boundary-layer height and its scales over a boreal forest, Boundary Layer Meteorol., 99, 429-450, 2001.

Klett, J. D.: Stable analytical inversion solution for processing lidar returns, Appl. Opt., 20, 211-220, 1981.
Mamouri, R. E., Papayannis, A., Tsaknakis, G., and Amiridis, V.: 6-month ground-based water vapour Raman lidar measurements over Athens, Greece and system validation, J. Optoelectr. Adv. Materials, 9, 3546-3548, 2007.

Markowicz, K. M., Flatau, P. J., Kardas, A. E., Remiszewskaj, J., Stelmaszcyk, K., and Wöste, L.: Ceilometer retrieval of the boundary layer vertical aerosol extinction structure, J. Atmos. Oceanic Technol., 25, 928-944, 2008.

Martucci, G., Milroy, C., and O' Dowd, C. D.: Detection of Cloud-Base Height Using Jenoptik CHM15K and Vaisala CL31 Ceilometers, J. Atmos. Oceanic Technol., 27, 305-318, 2010.

Matthias, V. and Bösenberg, J.: Aerosol climatology for the planetary boundary layer derived from regular lidar measurements, Atmos. Res., 63, 221-245, 2002.

Matthias, V., Freudenthaler, V., Amodeo, A., Balin, I., Balis, D., Bösenberg, J., Chaikovsky, A., Chourdakis, G., Comeron, A., Delaval, A., De Tomasi, F., Eixmann, R., Hågård, A., Komguem, L., Kreipl, S., Matthey, R., Vincenzo, R., Rodrigues, J. A., Wandinger, U., and Wang, X.: Aerosol lidar inter-comparison in the framework of the EARLINET project. 1. Instruments, Appl. Opt., 43, 961-976, 2004.

McKendry, I. G., van der Kampa, D., Strawbridge, K. B., Christen, A., and Crawford, B.: Simultaneous observations of boundarylayer aerosol layers with CL31 ceilometer and 1064/532 nm lidar, Atmos. Environ., 43, 5847-5852, 2009.

Menut, L., Flamant, C., Pelon, J., and Flamant, P. H.: Urban boundary-layer height determination from lidar measurements over the Paris area, Appl. Opt., 38, 945-954, 1999.

Michalsky, J., Schlemmer, J., Berkheiser, W., Berndt, J., Harrison, L., Laulainen, N., Larson, N., and Barnard, J.: Multiyear measurements of aerosol optical depth in the atmospheric radiation measurement and quantitative links programs, J. Geophys. Res., 106, 12099-12107, 2001.

Münkel, C. and Räsänen, J.: New optical concept for commercial lidar ceilometers scanning the boundary layer, Proc. SPIE, 5571, 364(2004), doi:10.1117/12.565540, 2004.

Münkel, C., Eresmaa, N., Räsänen, J., and Karppinen, A.: Retrieval of mixing height and dust concentration with lidar ceilometer, Boundary Layer Meteorol., 124, 117-128, 2007.

Papayannis, A. and Balis, D.: Study of the structure of the lower troposphere over Athens using a backscattering lidar during the MEDCAPHOT-TRACE Experiment: Measurements over a suburban area, Atmos. Environ., 32, 2161-2172, 1998.

Papayannis, A., Balis, D., Amiridis, V., Chourdakis, G., Tsaknakis, G., Zerefos, C., Castanho, A. D. A., Nickovic, S., Kazadzis, S., and Grabowski, J.: Measurements of Saharan dust aerosols over the Eastern Mediterranean using elastic backscatter-Raman lidar, spectrophotometric and satellite observations in the frame of the EARLINET project, Atmos. Chem. Phys., 5, 2065-2079, doi:10.5194/acp-5-2065-2005, 2005.

Papayannis, A., Amiridis, V., Mona, L., Tsaknakis, G., Balis, D., Bösenberg, J., Chaikovski, A., De Tomasi, F., Grigorov, I., Mattis, I., Mitev, V., Müller, D., Nickovic, S., Pérez, C., Pietruczuk, A., Pisani, G., Ravetta, F., Rizi, V., Sicard, M., Trickl, T., Wiegner, M., Gerding, M., Mamouri, R. E., D’Amico, G., and Pappalardo, G.: Systematic lidar observations of Saharan dust over Europe in the frame of EARLINET (2000-2002), J. Geophys. Res., 113, D10204, doi:10.1029/2007JD009028, 2008.

Papayannis, A., Mamouri, R. E., Amiridis, V., Kazadzis, S., Pérez, 
C., Tsaknakis, G., and Kokkalis, P.: Systematic lidar observations of Saharan dust layers over Athens, Greece in the frame of EARLINET project (2004-2006), Ann. Geophys., 27, 36113620, 2009,

http://www.ann-geophys.net/27/3611/2009/.

Pappalardo, G., Amodeo, A., Pandolfi, M., Hiebsch, A., Mattis, I., Amodeo, A., Ansmann, A., Seifert, P., Linnè, H., Apituley, A., Alados Arboledas, L., Balis, D., Chaikovsky, A., Comeron, A., DAmico, G., Freudenthaler, V., Grigorov, I., Papayannis, A., Perrone, M. R., Pietruczuk, A., Pujadas, M., Rizi, V., Spinelli, N., Wang, X., and Wiegner, M.: Aerosol lidar inter-comparison in the framework of the EARLINET project. 3. Raman lidar algorithm for aerosol extinction, backscatter and lidar ratio, Appl. Opt., 43, 5370-5385, 2004.

Seinfeld, J. H. and Pandis, S. N.: Atmospheric Chemistry and Physics, from Air Pollution to Climate Change (2nd Edn.), John Wiley, New York, 2006.
Stull, R. B.: An Introduction to Boundary Layer Meteorology. Kluwer Acad. Publishing, The Netherlands, 1988.

Vaisala User's Guide, Vaisala ceilometer CL31, Vaisala Oyj, Helsinki, Finland, 2009.

Wang, X., Boselli, A., D’Avino, L., Pisani, G., Spinelli, N., Amodeo, A., Chaikovsky, A., Wiegner, M., Nickovic, S., Papayannis, A., Perrone, M. R., Rizii, V., Sauvage, L., and Stohl, A.: Volcanic dust characterization by EARLINET during Etna's eruptions in 2001-2002, Atmos. Environ., 42, 893-905, 2008. 